\title{
Emission of Combustible Gases at Traffic and Practising Waste Dumpsite in Freetown, Sierra Leone: A Pilot Study
}

\author{
Bunting Kayode Williams ${ }^{1 *}$, Joe Milton Beah ${ }^{1}$, Eldred Tunde Taylor ${ }^{1}$, Thomas Fayia Kamara ${ }^{2}$, \\ Daniel Kaitibi ${ }^{3}$
}

${ }^{1}$ Institute of Environmental Management and Quality Control, School of Environmental Sciences, Njala University, Main Campus, Njala, Sierra Leone

${ }^{2}$ Department of Biological Sciences, School of Environmental Sciences, Njala University, Main Campus, Njala, Sierra Leone ${ }^{3}$ Department of Physics and Computer Science, School of Technology, Njala University, Main Campus, Njala, Sierra Leone

Email: *kayebunt@yahoo.com, etaylor@njala.edu.sl

How to cite this paper: Williams, B.K., Beah, J.M., Taylor, E.T., Kamara, T.F. and Kaitibi, D. (2017) Emission of Combustible Gases at Traffic and Practising Waste Dumpsite in Freetown, Sierra Leone: A Pilot Study. Atmospheric and Climate Sciences, 7, $1-10$.

http://dx.doi.org/10.4236/acs.2017.71001

Received: September 5, 2016

Accepted: December 4, 2016

Published: December 7, 2016

Copyright $\odot 2017$ by authors and Scientific Research Publishing Inc. This work is licensed under the Creative Commons Attribution International License (CC BY 4.0).

http://creativecommons.org/licenses/by/4.0/

\section{Open Access}

\begin{abstract}
An assessment of the emission of combustible gases in developing countries requires reliable analytical realtime monitors that can rapidly screen them with minimal handling. Considering the expensive nature of monitoring environmental pollutants, chemical sensors are expected to play a pivotal role in measuring and recording environmental data. The Drager X am 5000 was used to report emission levels of combustible gases in this study, namely; nitrogen dioxide $\left(\mathrm{NO}_{2}\right)$, sulphur dioxide $\left(\mathrm{SO}_{2}\right)$ and carbon monoxide ( $\mathrm{CO}$ ) at traffic and practising waste dumpsite in Freetown, the main city of Sierra Leone. Hourly average values for the three pollutants were recorded in the morning, afternoon and evening periods, respectively. The range of values were $18-76 \mathrm{ppb}$ for $\mathrm{NO}_{2}, 211-506 \mathrm{ppb}$ for $\mathrm{SO}_{2}$ and $11-14 \mathrm{ppm}$ for $\mathrm{CO}$ at traffic site; and $6-16 \mathrm{ppb}$ for $\mathrm{NO}_{2}, 118-276 \mathrm{ppb}$ for $\mathrm{SO}_{2}$ and $8-15 \mathrm{ppm}$ for $\mathrm{CO}$ at the dumpsite, respectively. There were significantly high hourly variations for $\mathrm{NO}_{2}$ and $\mathrm{SO}_{2}$ at the traffic site and for $\mathrm{CO}$ and $\mathrm{SO}_{2}$ at the dumpsite. Evidence of peak values showed emission levels that were considered dangerous for human exposure. This pilot study revealed that combustible gases released in certain areas of the capital city are a concern for both public health officials and environmental advocates.
\end{abstract}

\section{Keywords}

Pollution, Nitrogen Dioxide, Sulphur Dioxide, Carbon Monoxide, Air Quality

\section{Introduction}

Urban air pollution is increasingly getting global attention as reported by World Health 
Organization (WHO). It is reported that millions of people around the world are exposed to dangerous levels of air pollution. Several key stakeholders such as environmental health research community, environmental regulatory bodies, industries, transport etc. have drawn keen interest on air pollution and public health. The quality of the outdoor or ambient air is tied closely to morbidity and mortality from respiratory and cardiovascular diseases [1] [2] [3] [4]. Common urban air pollutants that have been on the spotlight include nitrogen dioxide $\left(\mathrm{NO}_{2}\right)$, sulphur dioxide $\left(\mathrm{SO}_{2}\right)$ and carbon monoxide (CO). They are usually released from either stationary or mobile sources in urban areas.

Sulphur in the lower troposphere originates either from natural processes or anthropogenic activity. $\mathrm{SO}_{2}$ is a renowned anthropogenic pollutant and contributes to the formation of sulphuric acid and formation of sulphate aerosols, and the deposition of sulphate and $\mathrm{SO}_{2}$ on the surface of the ground. Direct emission of $\mathrm{SO}_{2}$ is generally by burning fuels containing sulphur which is largely responsible for its presence. It can undergo several processes such as transformation due to atmospheric reactions such as gas to particle conversion and eventually wet and dry deposition. These processes perturb the environment negatively that consequently results in acid rain [5]. Nitrogen dioxide is a constituent mixture of nitrogen oxides $\left[\mathrm{NO}_{\mathrm{x}}=\mathrm{NO}+\mathrm{NO}_{2}\right]$ and it is mostly formed during combustion processes. Mobile and stationary combustion sources have been reported to be the major anthropogenic source of $\mathrm{NO}_{2}$ in the atmosphere [6] [7]. $\mathrm{NO}_{2}$ is alongside $\mathrm{NO}$, a major regulator of the oxidizing ability of the troposphere through regulating the buildup and fate of radical species including hydroxyl radicals. It is a precursor of ozone $\left(\mathrm{O}_{3}\right)$ during photochemical formation and therefore influences its concentration in the lower troposphere and also plays a significant role in photochemical smog.

$\mathrm{CO}$ is a byproduct of incomplete combustion of diesel or gasoline engines in traffic, industrial operations, dumpsites of municipal solid waste where open burning is practiced, cooking with biomass in less ventilated stoves, etc. The rapid growth of the capital city Freetown, is considered to have a profound effect on the air quality situation, for instance, emission due to the rapid increase of two stroke engines, increased use of second hand vehicles and poor quality fuels [8] [9] [10]. Freetown has an array of environmental and public health problems including respiratory illnesses due to high levels of pollution [11]. Hence, this study focuses on a weeklong air quality screening at two potential sites of emission of $\mathrm{NO}_{2}, \mathrm{SO}_{2}$ and $\mathrm{CO}$ in Freetown, so as to assess emission levels of these combustible gases in the lower atmosphere.

\section{Methodology}

\subsection{Study Area}

Sierra Leone lies within the West African tropical rainforest belt, although the drier northern areas are transitional between this zone and the savannah belt to the north. The Tropical Front in Sierra Leone lies mainly to the south from December until March and there is very little rain during this dry season. About April, the Tropical Front moves northwards and the country falls under the southwest monsoonal rains from May to October. In November, the Front moves southwards again bringing the return 
of the dry winds. Thunderstorms are common during the change-over periods between the seasons. The duration of the "Harmattan" period decreases southwards; conversely, the rainfall increases considerably and is heaviest on the coast while Musaia (in Koinadugu District) in the far north of the country is the driest.

In Freetown, the highest temperatures (average $=31^{\circ} \mathrm{C}$ ) are experienced at the peak of the dry season in March, whilst the lowest temperatures (average $=23^{\circ} \mathrm{C}$ ) are recorded during the wet season from July to October. Also, the highest rainfall period is between June and October, with the precipitation reaching its peak during the month of August. Freetown was selected for the study because it is the capital city of Sierra Leone where more than two-thirds of the country's automobile exists. It is located on the Western Area of the country on a mountainous peninsula stretching into the Atlantic Ocean.

\subsection{Site Description}

Traffic site: The EASTEND POLICE intersection was selected. It is located in the East end of the city linking the peripheral or sub-urban areas to the central business district. It is the main entry point into the city center via Kissy Road intersecting Fourah Bay Road; a route mostly used by office workers, school-going children, business people, etc. This same route is used by heavy vehicles, with over 4 tons capacity, into the city center conveying imported goods from the Sea Port or Provinces. Traffic jams are quite obvious due to these heavy vehicles that often brokedown along the main road giving rise to endless queues of traffic. Parked vehicles along the roadside also contribute to the poor traffic situation. Commercial activities are quite visible along the narrow strip of pedestrian pathway, with petty traders often blocking the narrow footpath. Fairly high rising buildings that are less than 2 - $3 \mathrm{~m}$ away from the roadside are noticeable, depending on the area.

Waste Disposal Site: This site is located in a valley of the Granville Brook stream which runs across Bai Bureh road and opens up into the Atlantic Ocean; the surrounding communities are fully urbanized within a residential area. The site is bounded to the east by the valley wall and to the south by the main highway exiting the city center. The west of the site is limited by the Granville Brook stream channel and is open ended to the north where the Granville Brook joins the Sierra Leone River. The dumpsite receives all categories of solid waste as well as liquid waste from various sources such as domestic, hospital, industries etc. Even though "Masada" Company which is charged to manage wastes in the capital has been making huge strides to create a conducive environment for waste management in the past three years, yet, waste is dumped indiscriminately and left untreated and uncovered.

\subsection{Sampling Program}

\subsubsection{Instrumentation}

The concentration of combustible gases $\mathrm{NO}_{2}, \mathrm{SO}_{2}$ and $\mathrm{CO}$ were measured during this study using the Drager X-am 5000 obtained from Ribble Enviro Ltd., UK;

(www.drager.com). It is a small, light and easy to use equipment, which makes it very ideal for field monitoring in areas where conventional monitoring requirements are 
somehow restricted. It is very robust, water-tight and is designed for single-handed operation in tough industrial environments. According to IP 67, it is water and dustproof and contains an integrated rubber boot which provides the device optimal functionality even under harsh conditions. The monitor can measure up to six gases simultaneously but for the purpose of this study, three (3) electrochemical infrared sensors for $\mathrm{NO}_{2}$, $\mathrm{SO}_{2}$ and $\mathrm{CO}$ were utilized. The device has a high resolution of $0.1 \mathrm{ppm}$ for both $\mathrm{NO}_{2}$ and $\mathrm{SO}_{2}$ and 2 ppm for $\mathrm{CO}$ with very short response times of 15 seconds for $\mathrm{NO}_{2}$ and $\mathrm{SO}_{2}$ and 25 seconds for $\mathrm{CO}$. Measurements were recorded at regular intervals of one (1) hour duration at each site in the morning period, between the hours of 07h00 - 09h00, afternoon from $12 \mathrm{~h} 00$ - $14 \mathrm{~h} 00$ and evening from 17h00 - 19h00 from both sites over a five-day period. Measurements were recorded at five (5) minutes intervals.

\subsubsection{Positioning of Samplers}

The sampling was carried out in mid-December 2015 at the two sites. The sampling sites were selected to reflect ambient concentrations of the pollutants released from these two sources in Freetown. A monitoring height of $1.2 \mathrm{~m}$ above ground was used during the monitoring. Care was taken to ensure that the sampler was not exposed to the risk of spontaneous fire outbreaks at the dumpsite by keeping a safe distance away from continuously burning garbage. This was especially necessary for situations in which the emitted plume of gases from the dumpsite was blown directly towards the monitoring personnel by the wind. The monitoring duration for each cycle of measurement was one hour.

\subsection{Quality Control Procedures}

The zero point accuracy of the sensors was reached by carrying out the fresh air calibration each time measurement was made in order to correct instrument drift. Significant drift may interfere with data quality and this was achieved by the one-button calibration procedure in an area away from the monitoring zone or area where trace levels of the measured gases or interfering gases are found. Field assistants had to move to the middle of nearby secondary school campuses where there is little evidence of ambient air pollution to carryout fresh air calibration. The display containing the current gas concentration changes with the display showing "OK" when calibration was done indicating a successful calibration process.

\subsection{Data Analysis}

Quantitative and numeric data were obtained during the study which was then subjected to descriptive statistics. Five minutes averages were computed within an hour to obtain hourly averages for the morning, afternoon and evening periods; t-test was used to compare mean concentrations for $\mathrm{NO}_{2}, \mathrm{SO}_{2}$ and $\mathrm{CO}$ between the traffic site and the dumpsite. Since the data did not follow a normal distribution pattern, a Wilcoxon non-parametric test was used to test whether group means are similar across each pollutant $\left(\mathrm{NO}_{2}, \mathrm{SO}_{2}\right.$ and $\left.\mathrm{CO}\right)$. A threshold value of significance ( $p$ value) was taken at $5 \%$ or 0.05 from which all statistical inferences were made. These analyses were conducted using JMP 8 statistical package. Results are presented in the form of charts. 


\section{Results and Discussion}

Results of three air pollutants of interest namely, $\mathrm{NO}_{2}, \mathrm{SO}_{2}$ and $\mathrm{CO}$ were recorded for the two sites monitored in Freetown. Figure 1, revealed the spatial and temporal variation of air quality indicators between the two sites. It can be observed that there were significant elevations of $\mathrm{NO}_{2}$ in the morning and afternoon periods at the traffic site relative to the dumpsite. A similar observation was again manifested for $\mathrm{SO}_{2}$ between the sites but only a significant difference was noted for $\mathrm{CO}$ in the afternoon period.

Generally, levels of pollutants were higher in the traffic site relative to the dumpsite and a probable reason for such observation could be due to low general circulation of air and thus more stagnant air masses resulting in more accumulation of pollutants. Given the open area of the dumpsite facing the Atlantic Ocean, the high wind speed and sudden changes in general wind direction might have affected and aided the dispersion of gases emitted at the dumpsite, hence low level of pollution observed. The dispersion of gases has further being enhanced over the past few years considering the responsibilities of MASADA, a company charged to manage municipal wastes in the city. The company has been engaged in clearing areas down towards the Atlantic Ocean so as to restrict the neighborhood from illegal disposal of wastes. Dispersion of air pollutants by wind
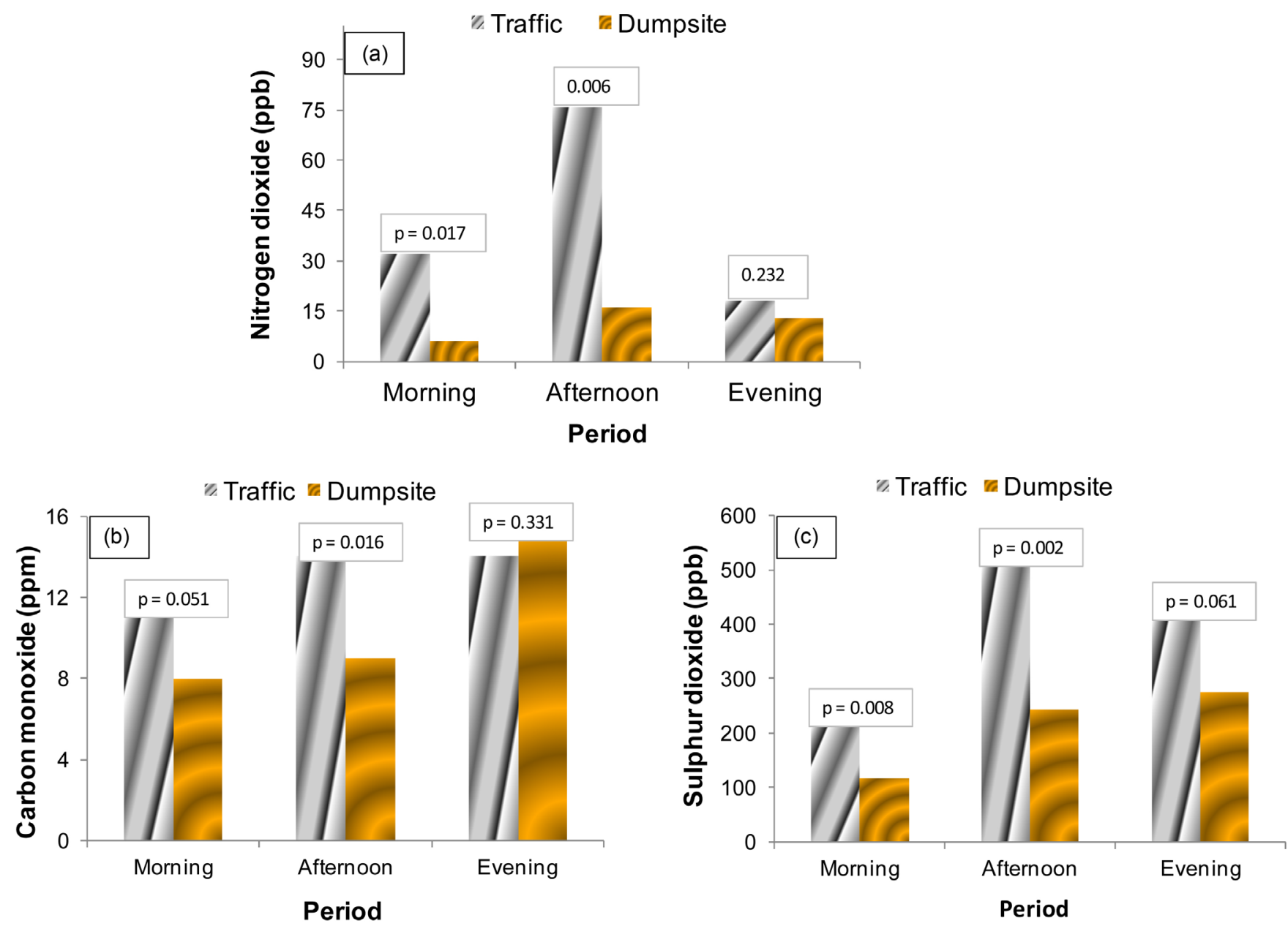

Figure 1. Spatial and temporal distributions of air pollutants across traffic and practising dumpsite for (a) $\mathrm{NO}_{2}$ levels (b) $\mathrm{SO}_{2}$ levels and (c) CO levels. 
enhances further dilution of the gas concentrations and there is a greater tendency to transport them further inland where they are not generated posing health risks to residents.

The highest levels of $\mathrm{NO}_{2}$ and $\mathrm{SO}_{2}$ were recorded in the afternoon period at the traffic site. This observation is in agreement with a previous study in Tanzania along a busy road site (Askari) showing relatively higher levels of $\mathrm{NO}_{2}$ and $\mathrm{SO}_{2}$ in the afternoon period relative to the morning period [12] but similar observable levels have been reported in Lagos, Nigeria [13] even though the sampling or monitoring regime is different. Average values of $\mathrm{NO}_{2}$ and $\mathrm{SO}_{2}$ in this study are lower than what the study in Tanzania reported [12], but the $\mathrm{SO}_{2}$ levels in the current study is higher than a previous study in India for all the months being monitored [6] although variation in the study design exists. However, in countries where stricter emission controls are enforced such as in Japan and India, our reported levels are by far higher than what has been reported [3] [14].

Empirical evidence has shown that $\mathrm{NO}_{2}$ is low during periods of sunshine usually in tropical or sub-tropical regions [6]. It should be observed that the formation of $\mathrm{NO}_{2}$ depends on the atmospheric condition and primary emission source of NO [15]. Due to its reactivity with other species in the atmosphere, $\mathrm{NO}_{2}$ can undergo complex photochemical reactions. Previous evidences have shown a reduction in $\mathrm{NO}_{2}$ levels during the summer or periods of intense sunshine [16] [17] and we are of the view that the source and sink pathway of this species is rather complicated.

According to Figure 2, the 1-hr average levels showed significant variation for $\mathrm{NO}_{2}$ with the highest variance being observed in the afternoon at the traffic site. No such difference in variation was noted for $\mathrm{CO}$ for the various monitoring periods but there was a considerable variation for $\mathrm{SO}_{2}$. Figure 3 also showed significant variation in values for $\mathrm{SO}_{2}$ and $\mathrm{CO}$ at the practising dumpsite relative to $\mathrm{NO}_{2}$.

The observed variation in the afternoon along the traffic site according to Figure 2 is strongly attributed to the change in the flow of vehicle pattern. This period is characterized by entry into and exit from the city center by heavy duty vehicles that carry goods and services. Although this period should be considered off-peak period, yet, the levels are higher due to endless queue of traffic. It was observed from Figure 2 that the short term exposure can be astonishingly high as evident in the peak or maximum values. All three indicator species showed critical values that exceeded ambient air quality standards for any reference period. For instance, peak exposure can reach $240 \mathrm{ppb}$ for $\mathrm{NO}_{2}$, $1900 \mathrm{ppb}$ for $\mathrm{SO}_{2}$ and $70 \mathrm{ppm}$ for $\mathrm{CO}$, an indication that critical values for $\mathrm{NO}_{2}$ can be 4 - 5 times higher, $\mathrm{SO}_{2} 25$ times higher and $\mathrm{CO}$ is 2 times higher than ambient thresholds, respectively. There is a growing body of evidence of strong association between combustible gases and health outcomes. For instance, previous studies have revealed association between $\mathrm{NO}_{2}$ and $\mathrm{CO}$ and cardiac problems in patients [18] [19]. Other studies have reported elevated levels of gaseous air pollutants and worsening asthma conditions in patients and daily mortality [20] [21].

In Sierra Leone, most of the vehicles are powered by gasoline and the evidence of sulphur compounds in the atmosphere of Freetown could be an indication that fuels imported into the country contain sulphur. It has been earlier reported that $\mathrm{SO}_{2}$ is a 

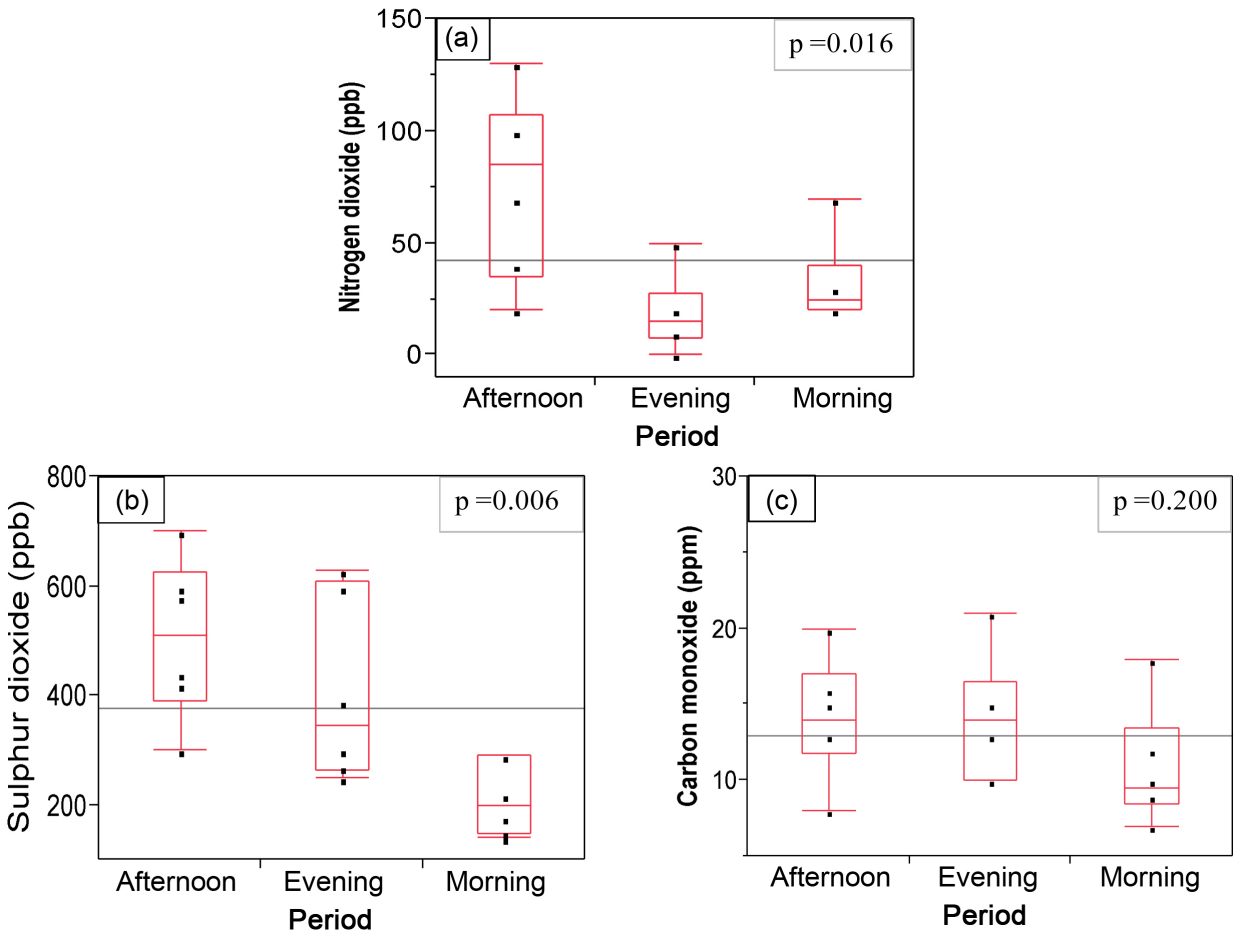

Figure 2. Box plots showing hourly variation at traffic site for (a) $\mathrm{NO}_{2}, \mathrm{p}=0.016$; (b) $\mathrm{SO}_{2}, \mathrm{p}=$ 0.006 and (c) CO, $\mathrm{p}=0.200$.
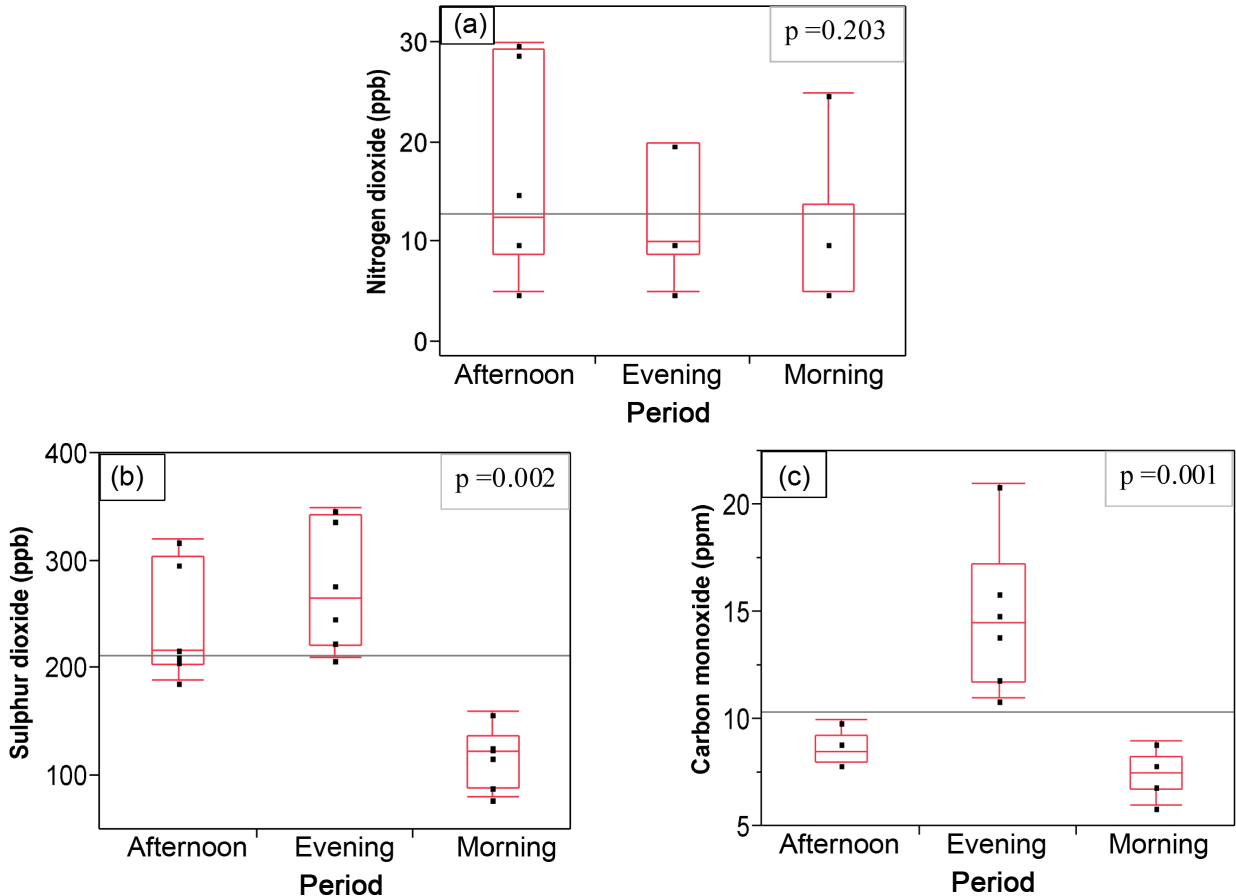

Figure 3. Box plots showing hourly variation at practising dumpsite for (a) $\mathrm{NO}_{2}, \mathrm{p}=0.203$; (b) $\mathrm{SO}_{2}, \mathrm{p}=0.002$ and (c) $\mathrm{CO}, \mathrm{p}=0.001$.

conventional air pollutant that is released into the atmosphere mainly from anthropogenic sources like combusting sulphur containing fossil fuel [16]. Whilst $\mathrm{SO}_{2}$ levels in cities of other countries outside Africa appear to have declined due to stricter emission 
controls [21] [22] and increased use of low sulphur fuel, the situation in developing countries such as Sierra Leone is different as evident in this study. One direct environmental impact of high levels of sulphur dioxide in Freetown is the formation of acid rain given the heavy downpour of rain in that part of the country. Considering the fragile state of the water resources in the country, this foreseeable problem needs urgent policy action.

The air quality of Freetown would continue to be challenging if urgent regulations are not passed into law by the government. Key considerations in the regulations should include; levy more or higher taxes on all used imported vehicles rather than on brand new vehicles; discourage the practice of open burning of domestic wastes with tougher penalties for defaulters; rigorous testing for sulphur content in all imported fuels; stop all street trading along traffic routes in the city so as to avail footpath for pedestrians and protect traders (mainly women and children) from exposure to high emission levels; reduce the flow of heavy tonnage vehicles during the day; development of effective waste management system etc. In addition, we strongly agree with the integrated approach put forward [23] to addressing the problem of air pollution in developing countries [23]. This should include emission inventories focusing on characterizing pollutants and their sources; followed by atmospheric modeling which provides the basis of spatial and temporal coverage of the area. When the modeling provides adequate representation of the measurements made through the ambient monitoring program, then the process can continue with further modeling, both primary (human health) and secondary (welfare) effects [23]. It is only through this approach that decision makers can reach beyond the boundaries of geography and divergent interests to develop effective policies to achieve improved air quality.

\section{Conclusion}

In this pilot study, we determined the emission levels of $\mathrm{NO}_{2}$ and $\mathrm{SO}_{2}$ and $\mathrm{CO}$ at a busy traffic road and a practicing waste dumpsite in Freetown where similar meteorological conditions were present. The results revealed relatively higher emissions at the traffic site than the waste dumpsite although significant differences in emissions were noted for the morning, afternoon and evening periods between the two sites. This piece of work provides valuable background information that can be guided in dispersion modeling as well as evaluating the possible impacts from mobile and stationary sources. It is strongly recommended that a long term monitoring program should be done so as to observe meteorological influences on pollution episodes.

\section{Acknowledgements}

This study was part of the student's requirement to complete the degree program in Environmental Management and Quality Control, School of Environmental Sciences, Njala University. Many special thanks is extended to all the people who helped in the field monitoring particularly those who helped with proofreading and typesetting of the manuscript.

\section{References}

[1] Peel, J.L., Tolbert, P.E., Klein, M., Metzger, K.B., Flanders, W.D., Todd, K., Mulholland, 
J.A., Ryan, P.B. and Frumkin, H. (2005) Ambient Air Pollution and Respiratory Emergency Department Visits. Epidemiology, 16, 164-174. https://doi.org/10.1097/01.ede.0000152905.42113.db

[2] Dales, R. (2004) Ambient Carbon Monoxide May Influence Heart Rate Variability in Subjects with Coronary Heart Disease. Journal of Occupational Environment and Medicine, 46, 1217-1221.

[3] Jayaraman, N.G. (2007) Air Quality and Respiratory Health in Delhi. Environmental Monitoring and Assessment, 135, 313-325. https://doi.org/10.1007/s10661-007-9651-0

[4] Boman, C., Forsberg, A.B. and Jarvholm, B.G. (2003) Adverse Health Effects from Ambient Air Pollution in Relation to Residential Wood Combustion in Modern Society. Scandenavian Journal of Work, Environment and Health, 29, 251-260. https://doi.org/10.5271/sjweh.729

[5] Singh, A. and Agrawal, M. (2008) Acid Rain and Its Ecological Consequences. Journal of Environmental Biology, 29, 15-24.

[6] Kaushik, C.P., Ravindra, K., Yadav, K., Mehta, S. and Haritash, A.K. (2006) Assessment of Ambient Air Quality in Urban Centers of Haryana (India) in Relation to Different Anthropogenic Activities and Health Risks. Environmental Monitoring and Assessment, 122, 22-40. https://doi.org/10.1007/s10661-005-9161-x

[7] Kandasamy, G., Moodley, S.S. and Suendran, G. (2011) Passive Monitoring of Nitrogen Dioxide in Urban Air: A Case Study of Durban Metropolis, South Africa. Journal of Environmental Management, 92, 2145-2150. https://doi.org/10.1016/j.jenvman.2011.03.040

[8] Lindén, J., Thorsson, S. and Eliasson, I. (2008) Carbon Monoxide in Ouagadougou, Burkina Faso-A Comparison between Urban Background, Roadside and In-Traffic Measurements. Water Air Soil Pollution, 188, 345-353. https://doi.org/10.1007/s11270-007-9538-2

[9] Halonen, J.I., Lanki, T., Yli-Toumi, T., Tittanen, P., Kulmala, M. and Pekkanen, J. (2009) Particulate Air Pollution and Acute Cardiorespiratory Hospital Admissions and Mortality among Eldrly. Epidemiology, 20, 143-153. https://doi.org/10.1097/EDE.0b013e31818c7237

[10] Gwilliam, K. (2003) Urban Transport in Developing Countries. Transport Review, 23, 197 216. https://doi.org/10.1080/01441640309893

[11] Taylor, E.T. and Nakai, S. (2012) Monitoring the Levels of Toxic Air Pollutants in the Ambient Air of Freetown, Sierra Leone. African Journal of Environmental Science and Technology, 6, 283-292.

[12] Othman, O.C. (2010) Roadside Levels of Ambient Air Pollutants: $\mathrm{SO}_{2}, \mathrm{NO}_{2}, \mathrm{NO}, \mathrm{CO}$ and SPM in Dar es Salaam City. Tanzania Journal of Natural and Applied Sciences, 1, 202-210.

[13] Olajire, A.A., Azeez, L. and Oluyemi, E.A. (2011) Exposure to Hazardous Air Pollutants Along Oba Akran Road, Lagos-Nigeria. Chemosphere, 84, 1044-1051. https://doi.org/10.1016/j.chemosphere.2011.04.074

[14] Tham, Y.W., Takeda, K. and Sakugawa, H. (2008) Exploring the Correlation of Particulate PAHs, Sulfur Dioxide, Nitrogen Dioxide and Ozone, A Preliminary Study. Water Air and Soil Pollution, 194, 5-12. https://doi.org/10.1007/s11270-007-9611-x

[15] Han, X. and Naeher, L.P. (2006) A Review of Traffic-Related Air Pollution Exposure Assessment Studies in the Developing World. Environment International, 32, 106-120. https://doi.org/10.1016/j.envint.2005.05.020

[16] Gupta, A., Kumar, R., Kumari, K.M. and Srivastava, S.S. (2003) Measurement of $\mathrm{NO}_{2}$, $\mathrm{HNO}_{3}, \mathrm{NH}_{3}$ and $\mathrm{SO}_{2}$ and Related Particulate Matter at a Rural Site in Rampur, India. Atmospheric Environment, 37, 4837-4846. https://doi.org/10.1016/j.atmosenv.2003.07.008

[17] VintarMally, K. and Ogrin, M. (2015) Spatial Variations in Nitrogen Dioxide Concentrations in Urban Ljubljana, Slovenia. Moravian Geographical Reports, 23, 27-35. https://doi.org/10.1515/mgr-2015-0015 
[18] Metzger, K.B., Tolbert, P.E., Klein, M., Peel, J.L., Flanders, W.D., Todd, K., et al. (2004) Ambient Air Pollution and Cardiovascular Emergency Room Visits. Epidemiology, 15, 4656. https://doi.org/10.1097/01.EDE.0000101748.28283.97

[19] Yang, C.Y., Chen, Y.S., Yang, C.H. and Ho, S.C. (2004) Relationship between Ambient Air Pollution and Hospitalization for Cardiovascular Diseases in Kaohsiung, Taiwan. Journal of Toxicology Environmental Health, Part A, 67, 483-493. https://doi.org/10.1080/15287390490276502

[20] Lee, J.T., Kim, H., Song, H., Hong, Y.C., Cho, Y.S., Shin, S.Y., et al. (2002) Air Pollution and Asthma among Children in SEOUL, South Korea. Epidemiology, 13, 481-484. https://doi.org/10.1097/00001648-200207000-00018

[21] Kan, H., Wong, C.M., Vichit-Vadakan, N., Qian, Z., et al. (2010) Short-Term Association between Sulfur Dioxide and Daily Mortality: The Public Health and Air Pollution in Asia (PAPA) Study. Environmental Research, 110, 258-264. https://doi.org/10.1016/j.envres.2010.01.006

[22] Dursun, S., Kunt, F. and Taylan, O. (2015) Modelling Sulphur Dioxide Levels of Konya City Using Artificial Intelligent Related to Ozone, Nitrogen Dioxide and Meteorological Factors. International Journal of Environmental Science and Technology, 12, 3915-3928. https://doi.org/10.1007/s13762-015-0821-2

[23] Aneja, V.P., Agarwal, A., Roelle, P.A., Phillips, S.B., Tong, Q., Watkins, N. and Yablonsky, R. (2001) Measurements and Analysis of Criteria Pollutants in New Delhi, India. Environment International, 27, 35-42. https://doi.org/10.1016/S0160-4120(01)00051-4

Submit or recommend next manuscript to SCIRP and we will provide best service for you:

Accepting pre-submission inquiries through Email, Facebook, LinkedIn, Twitter, etc. A wide selection of journals (inclusive of 9 subjects, more than 200 journals)

Providing 24-hour high-quality service

User-friendly online submission system

Fair and swift peer-review system

Efficient typesetting and proofreading procedure

Display of the result of downloads and visits, as well as the number of cited articles

Maximum dissemination of your research work

Submit your manuscript at: http://papersubmission.scirp.org/

Or contact acs@scirp.org 